\title{
Русско-урянхайский суд в период протектората
}

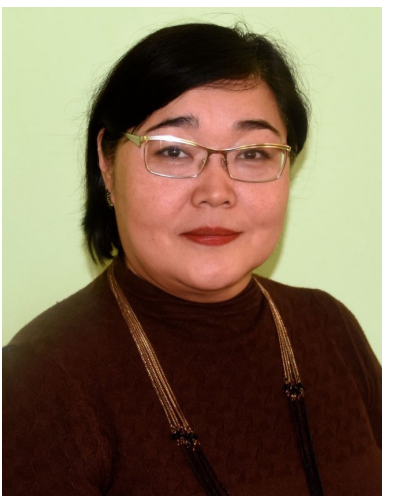

\author{
Вера М. Дамдынчап \\ Тувинский государственный университет, \\ Российская Федерация
}

Однако неопределенность правового статуса переселенцев осложняло их положение в Туве.

Приведены примеры многочисленных жалоб крестьян по поводу земельных споров с тувинцами. Тяжкие преступления как между русскими и тувинцами, так и между тувинцами рассматривались русским Волостным судом, а менее важные - урянхайским. В 1915 г. был создан смешанный русско-урянхайский суд. В его работе принимали участие выборные от русской власти и от местной. Введение смешанного суда не решало полностью земельные споры, но имело положительное значение для нормализации русско-тувинских отношений.

Ключевые слова: Урянхайский край; Тува; история Тувы; история права; обычное право; протекторат; суд; земельные споры; система наказаний; переселенческое управление

В статье анализируются проблемы правового регулирования общественвошений между тувинцами и русскими в туве в условиях установления Государственного архива Республики Тьва, Научного архива Тувинского института гуманитарных и прикладных социально-экономических исследований и др. Режим протектората предполагал зависимость Тувы во внешнеполитических делах, при сохранении внутренней самостоятельности. Административное управление осуществлялось Иркутским генерал-губернаторством, но не изменилась система административного управления, должности нойонов и их полномочия, действие обычного права. Русские переселенцы осваивали территории по частным соглашениям с чиновниками или зажиточными тувинцами и вопросами их обустройства занималось Переселенческое управление с 1912 г.

Дамдынчап В. М. Русско-урянхайский суд в период протектората [Электронный ресурс] // Новые исследования Тувы. 2019, № 1. URL: https://nit.tuva.asia/nit/article/view/834 (дата обращения: дд.мм. гг.). DOI: 10.25178/nit.2019.1.10

Дамдынчап Вера Монгушевна - кандидат исторических наук, доцент, заведующая кафедрой всеобщей истории, археологии и документоведения Тувинского государственного университета. Адрес: 667000, Россия, г. Кызыл, ул. Ленина, д. 36. Тел.: +7 (394-22) 3-00-92. Эл. адрес: damdvera@yandex.ru ORCID: 0000-0001-8477-7578

Damdynchap Vera Mongushevna, Candidate of History, Associate Professor, Head, Department of General History and Archeology, Tuvan State University. Postal address: 36 Lenina St., Kyzyl, 667000, Russia. Tel.: +7 (394-22) 3-00-92. E-mail: damdvera@yandex.ru 


\title{
Russian-Uriankhai court at the time of Russian protectorate over Tuva
}

\author{
Vera M. Damdynchap \\ Tuvan State University, Russian Federation
}

The article analyzes the problems of legal regulation of social relations between Tuvans and Russians in Tuva under the protectorate of the Russian Empire, and of resettlement of Russian peasants to the region in 1914-1917. For our sources, we have used unpublished materials from the State Archives of the Republic of Tyva, the Research Archives of the Tuvan Institute for the Humanities and Applied Socio-Economic Studies, as well as some other collections.

The regime of the protectorate assumed Tuva's dependence on Russia in foreign affairs, while allowing it to maintain internal autonomy. Administrative control was in the hands of the Irkutsk Governor-General, but the system of administration itself had not change, and neither did the position of the noyons, their powers and the effect of customary law. Russian immigrants claimed plots of land in accordance with private agreements with officials or wealthy Tuvans, and since 1912, the Resettlement department had also been involved. However, the uncertainty of the legal status of migrants complicated their position in Tuva.

The article provides examples of numerous peasants' complaints about their land disputes with Tuvans. Grievous crimes perpetrated by a member of one ethnic community against that of the other, or within the Tuvan community, were reviewed by the Russian Volost' Court, and those less severe, by the Uriankhai court. In 1915 a mixed RussianUriankhai court was set up, composed of elected representatives of the Russian community and local authorities. The newly-established mixed court failed to fully resolve land disputes, but had a positive impact on the RussianTuvan relations.

Keywords: Uriankhai region; Tuva; Tuvan history; history of law; customary law; protectorate; court; land disputes; system of punishment, Resettlement department

\section{For citation:}

Damdynchap V. M. Russian-Uriankhai court at the time of Russian protectorate over Tuva. The New Research of Tuva, 2019, no. 1 [on-line] Available at: https://nit.tuva.asia/nit/article/view/834 (accessed: ...). DOI: $10.25178 /$ nit.2019.1.10

\section{Введение}

В начале XX века геополитическая ситуация в Центральной Азии определялась ослаблением Китая и свержением в 1912 г. в ней правящей династии Цин. При этом Российская империя в этом регионе расширяла свое присутствие. Вопросу установления протектората России над Урянхайским краем, бывшей колонией Китайской империи, в научных исследованиях уделено достаточное внимание, к сожалению, вопрос о правовом регулировании отношений российским государством и тувинскими хошунами в условиях протектората раскрыт недостаточно. Историография темы включает работы разных лет, начиная от трудов дореволюционных русских ученых, описывавших Туву конца XIX - начала XX в., таких как, Г. Е. ГруммГржимайло, В. Родевич, Ф. Я. Кон (Грумм-Гржимайло, 1930; Родевич, 1910; Кон, 1914). В своих работах они раскрывают вопрос переселения старообрядцев в Туву. В советский период в научных исследованиях больше обращали внимание на политическое, социально-экономическое развитие Тувы. В работах советских исследователей рассматривался процесс установления протектората и его прогрессивное значение для истории тувинцев с точки зрения формационного подхода, например в работах В. М. Иезуитова, В. И. Дулова, Ю. Л. Аранчына (Иезуитов, 1956; Дулов, 1956; Аранчын, 1957, 1982). В 1964 г. вышла в свет «История Тувы», где вопрос о русско-урянхайском суде не раскрывался (История Тувы, 1964). Среди современных исследователей-тувиноведов следует отметить работы В. Г. Дацышена, в которых раскрываются русско-монгольские, русско-китайские отношения и вопросы русского заселения края, но в основном в плане внешнеполитических связей (Дацышен, 2002, 2005). 
Тем не менее, проблемы правового регулирования недостаточно исследованы учеными, например, вопросы взаимодействия тувинцев и русских крестьян-переселенцев в сфере землепользования, административно-территориального устройства, системы судопроизводства и др. В переработанном первом томе «Истории Тувы» довольно подробно освещен вопрос об установлении протектората и обострении противоречий между колонистами и местным населением, а также есть упоминание о смешанной комиссии для разрешения земельных споров, созданной заведующим русскими поселениями М. Я. Шкуновым и комиссаром Урянхайского края В. Ю. Григорьевым, но без разбора этой темы (История Тувы, 2001: 325-326).

В условиях многонационального населения в России сложилась в целом, терпимая политика по отношению к нерусским народам - инородцам. Еще в XIX в. был введен первый в истории страны документ, регулировавший отношения государства с народами Сибири «Устав об управлении инородцами», разработанный М. М. Сперанским в 1822 г. За основу были взяты обычаи и традиции селенгинских бурят, записанные в «Селенгинском уложении» ${ }^{\text {. Опыт }}$ управления сибирскими народами был реализован и на других национальных территориях, ставших российскими во второй половине XIX в. В Уставе заложены принципы терпимости и толерантности к обычаям и традициям народов. Освоение земель и приход русских переселенцев неминуемо приводили к конфликтам с местным населением, что усложняло установление мирных отношений с сибирскими народами. «Устав об управлении инородцами» отражал государственную политику в отношении сибирских народов. Признание обычноправовых институтов, учреждение инородческого суда и вменение обязанности разрешать уголовные и гражданские дела на основе исключительно писанных правовых документов формировали систему правового плюрализма в Сибири.

Целью данной статьи является анализ проблемы правового регулирования общественных отношений в условиях установления протектората и переселения русских крестьян. При написании статьи использовались неопубликованные материалы из фондов Государственного архива Республики Тыва, Научного архива Тувинского института гуманитарных и прикладных социально-экономических исследований и опубликованные архивные источники. В государственном архиве интересными и ценными являются материалы фондов 115 «Управления комиссара по делам Урянхайского края», 123 «Управление устройством русского населения», где содержатся прошения о земельных спорах и конфликтах переселенцев с местным населением (Оп. 1, Д. 1, Оп. 2, дд. 29, 45, 51, 60, 81, 94, 107, 108, 160). Также дела 114, 131, 141, где приводится статистическое обследование Урянхайского края. В Научном архиве ТИГПИ документы в фонде 42 находятся донесения, письма, заявления крестьян периода 1915-1917, 1920-1921 гг. В папке 4 сведения о земельном вопросе рассматривались на съездах русского населения 1915-1917 гг., доклад И. Г. Сафъянова о положении дел в Урянхае. Автором были написаны статьи по проблемам установления социальных отношений между русскими переселенцами и тувинцами, особенностей правопонимания института земельной собственности (Дамдынчап, 2006, 2009). Данная статья продолжает исследования.

\section{Политика Переселенческого управления и нарастание социальной напряженности}

В 1914 г. к российскому царю обратились тувинские нойоны с просьбой принять под покровительство России. Но обстановка не способствовала вхождению края в состав страны, Россия в это время вступила в Первую мировую войну. В таком случае единственным решением стало установление внешнеполитического протектората (Установление покровительства ..., 1994: 23).

Режим протектората предполагал зависимость территории во внешнеполитических делах,

\footnotetext{
${ }^{1}$ «Селенгинское уложение» 1775 г. является основным источником актов правотворчества хоринских, балаганских, идинских, кударинских бурят и других кочевых народов Сибири.
} 
но при сохранении внутренней самостоятельности. Подобный опыт Россия имела в отношениях с Младшим Жузом казахов (группой казахских родов и племен), взяв их под покровительство и постепенно включая их в состав государства. Такой подход не вызывал резких конфликтов. Но был опыт и со Средней Азией, когда первый генерал-губернатор Кауфман начал жесткую политику по установлению российских порядков, что естественно привело не только к конфликтам, но и восстанию жителей Коканда. Совет министров в отношении Урянхайского края рекомендовал вести осторожную политику по отношению к местному населению, стараться избегать конфликтов (История Тувы, 2001: 324).

Административное управление Тувой, находящейся под протекторатом, осуществлялось Иркутским генерал-губернаторством. Представителем российской власти был Комиссар по делам Урянхайского края, его заместителем считался Усинский пограничный начальник при Иркутстком генерал-губернаторе. При этом в Туве сохранялись прежняя система административного управления, должности нойонов и их полномочия, также формально сохранялось действие китайского Уложения и обычного права.

Первыми персонально зафиксированными русскими поселенцами в крае были минусинские купцы Веселков и Бяков. В 1857 г. Веселков начал торговлю в крае, Бяков в 1859 г. на p. Хемчик построил торговую факторию. Поскольку режим внешнеполитического покровительства не предполагал полного вхождения Тувы в состав Российской империи, соответственно на ее территорию не распространялись российские законы. Все должностные лица в своих действиях опирались на специальный документ - «Инструкцию должностнымъ лицамъ управленія Усинскаго пограничнаго Округа и Урянхайского края». Она была утверждена 29 июня 1914 г. министром внутренних дел Н. Маклаковым. В ней определялись должностные лица для управления Урянхайским краем и их полномочия: комиссар по делам края, Усинский пограничный начальник, заведующий устройством русского населения и др. (ГА РТ. Ф. 123, оп. 1, д. 1, л. 13). Переселенцы считались иностранцами на чужой территории, они получали заграничные билеты, формально оставаясь приписанными к своим губерниям и уездам (ГА РТ. Ф. 123, оп. 1, д. 1, л. 13об.).

В 1860-е гг. первыми русскими переселенцами были старообрядцы, которые «предпочитали заимочный способ освоения новых земель, тем самым страхуясь от возможных рисков неудачного закрепления на новой территории и осознавая свою незащищенность в случае возникновения конфликтов с местным населением» (Татаринцева, Стороженко, 2015: 28). Переселенцы селились на территории Тувы по частным соглашениям с чиновниками или зажиточными тувинцами, при этом устанавливалась плата за пользованием пашнями, сенокосами, за десятину в размере стоимости кирпича чая -3 руб. 50 коп. (ГА РТ. Ф. 123, оп. 2, д. 141, л. 37).

Для помощи в вопросах обустройства переселенцев была введена должность заведующего устройством русского населения, который занимался хозяйственными делами и обустройством переселенцев (Государственный архив Республики Тыва - далее ГА РТ. Ф. 123, оп. 1 , д. 1 , л. 14об.). Регулированием вопросов заселения русскими крестьянами тувинских земель занималось Переселенческое управление, которое появилось в Туве еще до установления формальных юридических отношений в 1912 г. Для сохранения правопорядка вводились полицейские участки на территории переселенцев, во главе с урядниками. Всего было три полицейских участка. (ГА РТ, Ф. 123, оп. 1, д. 1, Л. 257). Судебные дела поселенцев с 1914 г. передавались в ведение Усинского окружного суда, находившегося в ведении Красноярской Судебной Палаты.

Комиссаром по делам Урянхайского края был В. Григорьев, заведующим пограничными делами Усинского округа - А. Церерин, главой Переселенческого управления - В. К. Габаев.

Последний был наиболее активным сторонником полного подчинения Тувы, что нарушало правовые основы протектората. Его политика была более активной по обустройству переселенцев, что привело к конфликтам с тувинцами: 
«С приездом В. К. Габаева и топографов картина изменилась... без подготовки, резко было заявлено русским, что земли в указанных ими границах, принадлежатъ им и сойоты на них прав не имеютъ...» (ГА РТ. Ф. 123, оп. 2, д. 141, л. 38).

Другую позицию занимал А. Церерин:

«Вы командированы въ помощь мне и Ваша деятельность должна протекать подъ моимъ руководствомъ и надзоромъ и противъ всякихъ самостоятельных вашихъ выступлений как незаконныхъ я протестую» (ГА РТ. Ф. 123, оп. 2, д. 20, л. 35об.).

Он действовал в рамках указаний Иркутского генерал-губернатора.

Нойоны обращались к амбын-нойону с жалобами на самоуправство русских. Амбын-нойон дальше обращался с жалобами на самовольные захваты земель русскими поселенцами и требовал прекратить незаконное отмежевание у комиссара В. Григорьева (ГА РТ. Ф. 112, д. 153, л. 5).

Сложная политическая обстановка, хрупкая власть России в крае требовала разрешения ситуации. Попытки установить отношения в пределах правовых норм предпринял комиссар В. Григорьев:

«Если нетъ въ какой либо земль правосудія, которое защищаетъ обиженныхъ и наказываетъ обидчиковъ, то жители ея находятся обыкновенно въ тяжеломъ положеніи... Поэтому Русское Правительство, принявши подъ свое покровительство Урянхайскую землю, гдъ почти совершенно отсутствуетъ правосудіе, благодаря чему во многихъ мъстах замъчается большое развитіе своеволія сильныхъ и притьсненіе слабыхъ, где мъстами до крайности развилось конокрадство и скотокрадство... поставило своей задачей водворить среди Урянхайскаго населенія правосудіе. Для этого правительство съ одной стороны, стремится достичь того, чтобы въ тъхъ случаяхъ, когда действуетъ судъ Урянхайскихъ чиновниковъ, т. е. по деламъ сравнительно не большой важности этотъ судъ действовалъ возможно чаще и справедливъе, а с другой, чтобы Русскій Судъ дъламъ болъе важнымъ могъ действовать въ Урянхађ безпрепятственно» (ГА РТ. Ф. 123, оп. 1, д. 1, л. 258).

В начале 1915 г. В. Григорьев ввел обязательные правила по организации системы российского правосудия в Туве и обязывал тувинских чиновников оказывать содействие в его осуществлении (ГА РТ. Ф. 123, оп. 1, д. 1, л. 260). В хошунах для этой цели выделялся специальный особый чиновник - меринъ, который назначался комиссаром и следил за цзангами - правителями хошунов, чтобы те выполняли распоряжения главного начальника в Урянхае (ГА РТ. Ф. 123, оп. 1, д. 1, л. 260). Данное распоряжение было отправлено амбын-нойону, чтобы тот организовал избрание специальных чиновников и отправил список на утверждение комиссару.

Таким образом, была осуществлена попытка постепенного включения тувинских чиновников в систему управления через расширение правового пространства российского законодательства.

Тем не менее, в условиях внутреннего самоуправления нередко к русским поселенцам местные власти применяли нормы обычного права тувинцев в случаях правонарушений с их стороны. Примером является заявление комиссару Усинского округа и Урянхайского края от крестьянина Михаила Аткина:

«... нас держали целый год закованных в сойотской юрте в железных кандалах весом

в 3 пуда на шеи и руках, кормили кишками и всей скотской внутренностью, чаю давали один раз в день, редко 2 раза, когда мы убежали ... нас поймали, наказали так: повесили на дерево за ноги головой вниз на 2 часа и били палками, плетьми, караганником, а когда сняли нас, то целые сутки били и не давали спать» (Научный архив Тувинского института гуманитарных и прикладных социально-экономических исследований - далее НА ТИГПИ. Д. 42, л. 38.).

В 1915 г. в Переселенческое управление направлялись многочисленные жалобы поселенцев на действия тувинских чиновников и аратов, те в свою очередь предъявляли свои претен- 
зии местным властям (ГА РТ, Ф. 123, Оп. 2, Дд. 29, 45, 51, 94, 107, 108; НА ТИГПИ. Д. 42, л. 38-40, л. 194-271, 342-356].

Разрешить сложившуюся обстановку необходимо было компромиссным решением. Основные противоречия были основаны на различной природе права собственности на землю у кочевников и земледельцев. В понимании тувинцев земля принадлежит предкам, духамхозяевам местности, поэтому она не находится в чьей-либо собственности, люди пользуются ее благами с разрешения духов. А для русских крестьян земля является основным богатством, принадлежащим человеку, и обработанная земля является собственностью конкретного лица. Договоры, которые заключали переселенцы с тувинскими чиновниками, не означали перехода земли в собственность крестьян, а только передачу прав владения и пользования, поэтому, когда возникали земельные конфликты по поводу прогона скота через огороженные пашни или пользования сенокосами, то тувинцы требовали возвращения территорий.

\section{Введение Русско-Урянхайского суда}

В условиях усиления конфликтности комиссар приказал ввести смешанный суд. 27 февраля 1915 г. В. Ю. Григорьев подписал временные правила для смешанного суда на территории хемчикских (западных) хошунов, который начинал работу с 1 марта. В состав суда назначались два тувинских чиновника, причем один представлял Даа хошун и от русских властей один старший выборный, сроком на 1 год (ГА РТ. Ф. 123, оп. 1, д. 1, л. 61.). Появление такого суда имело положительное значение в нормализации отношений с тувинцами. В других хошунах русскоурянхайские смешанные суды появились позднее (ГА РТ, Ф. 123. оп. 1. д. 1, л. 113).

Во временных правилах устанавливалось рассмотрение дел между русскими и урянхами, а также по долговым обязательствам до 300 рублей. Иски можно было подать как письменно, так и устно. Решение по делу принималось большинством голосов. Обжалование решения суда возможно было только через обращение к заведующему устройством русского населения в Урянхайском крае в течение одной недели после вынесения решения суда. За неявку в суд устанавливался штраф от 1 до 10 рублей. При отказе оплатить данный штраф, виновный подвергался аресту от 1 до 3 дней. (ГА РТ. Ф. 123, оп. 1, д. 1, л. 61.).

Введение суда помогло снизить напряженность среду русских и тувинцев на Хемчике (ГА РТ. Ф. 123, ОП. 2. Д. 160).

С 1 сентября 1915 г. начал действовать смешанный суд уже в составе пяти судей: «изъ нихъ два судьи - урянха по выбору Урянхайского начальства, два судьи русскихъ по выбору русского населенія и председатель по назначенію Заведующаго устройствомъ русскаго населенія в Урянхађ» (ГА РТ. Ф. 123, оп. 1, д. 1, л. 113.). Все судьи выбирались на один год и для них устанавливался возрастной ценз - не моложе 25 лет. Судьи также не должны были иметь судимостей и находиться под следствием.

В русско-урянхайском суде рассматривались вопросы «по деламъ уголовныхъ и всякаго рода обиды, оскорбленія, самоуправства между русскими крестьянами и урянхами в пределахъ раіона смъшаннаго суда и кражи дневныя до 30 руб. и не имеющія признаков, перечисленных в ст. 170 Уст. о нак., по делам гражданским ведомству смешаннаго суда подлежать иски по всякаго рода долговым, письменными и словесным обязательствам и договорам на сумму в 300 руб.» (ГА РТ. Ф. 123. оп. 1. д. 1, л. 113).

Положение о смешанном суде основано было на российском законодательстве, в частности, на «Положении о крестьянах, вышедших из крепостной зависимости» 1861 г., действовавшего до 1917 г., а также на Положении «О земских участковых начальниках» 1889 г. Результатом введения этих актов стало создание системы самоуправления и волостного суда у крестьян. В 1889 г. был расширен круг лиц, на которых распространялось действие Волостного суда - мещан, ремесленников и др. Во временном положении о смешанном суде указывалось, что рассматриваются дела в пределах юрисдикции Волостного суда, а это споры и тяжбы 
между крестьянами в пределах 300 рублей. Волостной суд был сословным по своему характеру и рассматривал проступки на основе обычного права (Кузнецов, 1999: 98). В российской историографии волостной суд рассматривается исследователями как институт, сохранявший традиции и обычаи русской крестьянской общины (Безгин, 2015; Менщиков, 2016: 120).

В положении о смешанном суде в Туве были введены статьи из вышеуказанного общего положения. Логика понятна: зачем создавать что-то новое, если можно взять за основу, существующую действенную практику. Главная цель суда - примирение сторон. Поэтому была введена выборность судей от крестьян на общем сходе и двух их помощников (ГА РТ. Ф. 123. оп. 1. д. 1, л. 113об). Также и тувинские нойоны выбирали двух судей и их помощников. Конечно, положение о смешанном суде не было таким подробным, но в тексте есть прямые отсылки к российскому общему положению о крестьянах. В двух документах можно выявить много параллелей. Рассмотрим их.

Согласно российскому положению судебное слушание проходило устно, судебные решения принимались большинством голосов. Решения судей записывалось в специальные книги. В недельный срок сторонам выдавалось письменное решение, которое можно было обжаловать через подачу прошения заведующему устройством русского населения для рассмотрения на съезде крестьянских начальников. Разрешение конфликтов принималось на основании обычаев местности, что зафиксировано в п. 17 Положения о смешанном суде. Как отмечает В. Б. Безгин: «Обычно-правовое регулирование в крестьянской среде предусматривало решение всех спорных вопросов «на миру». Традиционная гласность крестьянского суда была проявлением взаимного нормативного контроля, гарантом соответствия решения неписаным нормам обычного права» (Безгин, 2015: 23).

В смешанном суде Тувы рассматривались дела и между тувинцами в пределах его юрисдикции. Не обжалованное решение считалось окончательным и приводилось в исполнение. Суд мог наложить три вида наказания: принудительные работы до 6 дней, денежное взыскание до 3 рублей, арест до семи дней (ГА РТ. Ф. 123. оп. 1. д. 1, л. 113об). В соответствии с п. 19 Положения о смешанном суде на основании Положения «О земских участковых начальниках» дела по земельным спорам разбирались заведующим устройством русского населения (ГА РТ. Ф. 123. оп. 1. д. 1, л. 113об). Как показывают архивные материалы, несмотря на довольно жесткую политику Габаева, дела по земельным конфликтам решались на основании обычаев тувинцев, хотя он старался узаконить факт приобретения земли.

Конечно, все конфликты не могли быть разрешены в судебном порядке, чаще всего тувинцы осуществляли свой суд в виде угонов скота у переселенцев (ГА РТ. Ф. 123, оп. 2, д. 141, л. 37об.).

Деятельность смешанного суда в течение двух лет повлияла на местное население, о чем писал в своем отчете 1917 г. усинский судья А. В. Барашков:

«Наконец, представляется ярко показательным очевидное усвоение туземцами понятий о праве русских на те урянхайские просторы, которые почитались ранее общими и ничьими, так подчиняясь справедливому решению русского суда по искам о потравах урянхи, в случае необходимости прогона скота через занятые земли стали не чуждаться неведомых им ранее обращения к местным властям с просьбой о разрешении такого прогона и содействии последних для избежания потравы» (ГА РТ. Ф. 123, оп. 2, д. 141, л. 405).

Заведующему подавали частые жалобы о потравах пашен скотом тувинцев, которые отказывались платить штраф по судебному решению (ГА РТ. Ф. 112, д. 270, л. 3). Приобретенные законно земли, как считали поселенцы, необходимо охранять и защищать, что они и требовали от российских властей (ГА РТ. Ф. 123, оп. 2, д. 141, л. 38).

Крестьяне могли и самовольно захватывать другие земли, что вызывало у тувинцев справедливое негодование, особенно в хошунах, где было развитое земледелие, богатые сенокосы. Естественно, кочевники ломали изгороди, мешавшие проходу скота к местам водопоя, пастбищам. На основании российских законов тувинцев присуждали к возмещению ущер- 
ба, что противоречило обычному праву (ГА РТ. Ф. 123, оп. 1, л. 123). Рассматривая такие конфликты, нойоны настаивали на том, что земли по договорам были переданы во временное пользование, а не в собственность (ГА РТ. Ф. 123, оп. 2, д. 94, л. 122). В большинстве случаев в смешанном суде принимали решение в пользу тувинцев. Крестьяне же обращались с жалобой о пересмотре решения суда или не выполняли его, что приводило к еще большему ожесточению отношений между тувинцами и русскими.

В докладе по Урянхайскому вопросу Минусинскому комитету общественной безопасности в 1917 г. Иннокентий Сафьянов ${ }^{1}$ представил сложное положение между русскими и урянхайцами:

«...меж ними идет глухая непримиримая вражда. Сойоты воруют скот у переселенцев, лошадей, а те ловят их и передают в руки ненавистного русского суда или же, подкараулив темной ночью, стреляют их как зайцев. В Минусинской тюрьме сидят двое урянхайских крестьян, отец и сын Ламикины, которые зарубили топорами двух пришедших к ним ночью сойот, принявъ их за конокрадовъ. Много нашумела в свое время история, как трое русских промышленников, застрелив, троих сойот и ранив четвертого, ограбили всю добытую ими в тайге пушнину. Драки между новопоселенцами и сойотами очень часто принимают характер малых сражений, в которых иногда принимали участие приставы и стражники. Так, пристав Александров с крестьянами брал приступом сойотский улус и захваченные ими в этом деле шесть человек, плененных сойот, были отправлены в Минусинскую тюрьму, где трое из них умерли, а трое были отправлены окружным судом на каторгу» (НА ТИГИ. Д. 42, л. 356-357).

Так, было очевидно, что введение смешанного суда не могло полностью нормализовать отношения между русскими и тувинцами. Ситуацию осложняла в целом геополитическая обстановка, когда зыбкой была еще судьба протектората, империя не могла пока укрепиться в регионе. Комиссар, заведующий стремились всячески укрепить российскую власть в Туве, обращались с просьбами к иркутскому генералу-губернатору о предоставлении более широких полномочий (ГА РТ. Ф. 123, оп. 1, д. 20, л. 33об.). Население в таких условиях пыталось и мирно решить конфликты, например, Оюннарский нойон просил съезд русских поселенцев рассмотреть возможность справедливого распределения сенокосов по р. Межегей между русскими и тувинцами (НА ТИГПИ. Д. 42, п. 4, л. 271).

Тем не менее, российские власти были осторожны в отношении Урянхайского края и запрещали обострять конфликты с местным населением (ГА РТ. Ф. 123, оп. 1, д. 1, л. 13 об.). Уже в 1916 г. в Урянхайский край переселилось более пяти тысяч крестьян при количестве примерно 56000 тувинцев (ГА РТ. Ф. 123, оп. 2, д. 20, л. 24, 29). В основном они селились не в густонаселенных хошунах, а в менее населенных тувинцами. Переселенческое управление проводило политику насильственных захватов территорий у тувинцев, без учета их интересов, что приводило к неминуемым конфликтам.

В период революционных событий в России 1917 г. обстановка стала постепенно меняться. 16 июня 1918 г. был заключен договор между русскими и тувинскими представителями о новых принципах взаимоотношений на основе дружбы и добрососедства. В этом документе переселение на территорию Урянхайского края, признанного независимым и самостоятельным, запрещалось, продажа земель прекращалась, самовольные захваты земель, сенокосов запрещались, мелкие правонарушения должны рассматриваться совместными комиссиями, а более важные дела передавались Русско-Урянхайскому съезду (НА ТИГПИ. Д. 42, п. 4, л. 275).

\section{Заключение}

Установление российского протектората и начало массового переселения русских крестьян на территорию Тувы обозначили новые вехи в истории Тувы. Вопрос о включении Тувы в со-

${ }^{1}$ Иннокентий Георгиевич Сафьянов в 1917 г. занимал должность городского головы г. Минусинска. 
став империи откладывался на неопределённый срок, поскольку Россия участвовала в Первой мировой войне. Сохранение внутренней самостоятельности в условиях усиления российского присутствия, невозможность в таких условиях полного распространения на Урянхай российского законодательства, а также разные традиции понимания института земельной собственности у тувинцев и русских переселенцев - все это создало условия для развития конфликтов между местным населением и вновь прибывшими, между властями. Тем не менее, осуществлялись и попытки компромиссного решения возникших конфликтов. Русско-урянхайский суд стал институтом, в котором власти стремились сочетать обычное право крестьянской общины и кочевого общества. Попытки решить конфликты на основе правового компромисса обусловлены опытом российской администрации по управлению другими национальными территориями.

Изучение опыта правового регулирования отношений между оседлым и кочевым населением в Урянхайском крае призвано привлечь внимание исследователей к проблеме взаимодействия различных правовых культур в едином политическом пространстве. Вопросы правового плюрализма, преемственности еще недостаточно изучены в истории Тувы и в дальнейшем требуют более полного исследования.

\section{СПИСОК ЛИТЕРАТУРЫ}

Аранчын, Ю. Л. (1957) Историческое значение присоединения Тувы к России в 1914 году // Ученые записки ТНИИЯЛИ. Кызыл. Вып. 5. С. 142-158.

Аранчын, Ю. Л. (1982) Исторический путь тувинского народа к социализму. Новосибирск : Наука. 337 с.

Безгин, В. Б. (2015) Волостной суд: особенности судопроизводства // Научные труды. Российская академия юридических наук / отв. ред. В. В. Гриб. М. : Издательство «Юрист». 1320 с. C. $68-72$.

Грумм-Гржимайло, Г. Е. (1930) Западная Монголия и Урянхайский край. Т. III. Вып. 2. Ленинград : Нев. тип. 456 с.

Дамдынчап, В. М. (2006) Владение и собственность в обычном праве тувинцев // Право в зеркале жизни. Исследования по юридической антропологии / отв. ред. Н. И. Новикова. М. : Издательский дом «Стратегия». 400 с. С. 215-231.

Дамдынчап, В. М. (2009) Правовая аккультурация обычного права тувинцев // Народы и культуры Южной Сибири и сопредельных территорий: история, современное состояние, перспективы: материалы междунар. науч. конф., посвящ. 65-летию ХакНИИЯЛИ, г. Абакан, 3-5 сентября 2009 г. / отв. ред. В. Н. Тугужекова. Абакан : Хакасское книжное изд-во. 186 с. C. $73-78$.

Дацышен, В. Г. (2002) Усинский пограничный округ. Власть и общество в пограничном регионе // Власть и общество. Региональные аспекты проблемы. (К 180-летию образования Енисейской губернии) / отв. ред. В. И. Федорова. Красноярск : Кларетианум. 186 с. С. 34-37.

Дацышен, В. Г. (2005) Саянский рубеж. Южная часть Приенисейского края и русско-тувинские отношения 1616-1911 гг. Томск : STT. 250 с.

Дулов, В. И. (1956) Социально-политическая история Тувы: XIX - начало XX в. М. : Изд-во AH CCCP. 326 c.

Иезуитов, В. М. (1956) От Тувы феодальной к Туве социалистической. Кызыл : Тувинское книжное издательство. 208 с.

История Тувы (1964) : в 2 т. / отв. ред. С. К. Тока. М. : Наука. Т. I. 455 с.

История Тувы (2001) / под общ. ред. С. И. Вайнтейна, М. Х. Маннай-оола. Новосибирск : Наука. Т. І. 367 с. 
Кон, Ф. Я. (1914) Усинский край / Зап. Красноярского подотдела ИРГО. Зап. по географии T. II. Вып. І. Красноярск : тип. б. М. И. Абалакова. 111 с.

Кузнецов, С. В. (1999) Обычное право в русской деревне и государственное законодательство во второй половине XIX века // Этнографическое обозрение. № 5. С. 97-110.

Менщиков, И. С. (2016) Волостной суд как хранитель традиционных норм поведения в русской деревне // Исторические, философские, политические и юридические науки, культурология и искусствоведение. Вопросы теории и практики. № 6-1 (68). С. 119-124.

Родевич, В. (1910) Очерк Урянхайского края (Монгольского бассейна реки Енисея). СПб. : Типография Министерства путей сообщения. 268 с.

Татаринцева, М. П., Стороженко, А. А. (2015) Старообрядцы в Туве: ретроспектива и современность. LAP LAMBERT Academic Publishing. 144 c.

Установление покровительства России над Тувой в 1914 г. (1994) : архивные документы / сост. В. А. Дубровский. Кызыл : Тувинское книжное издательство. 36 с.

Дата поступления: 20.12.2018 г.

\section{REFERENCES}

Aranchyn, Yu. L. (1957) Istoricheskoe znachenie prisoedineniya Tuvy k Rossii v 1914 godu [The historical significance of the accession of Tuva to Russia in 1914]. Uchenye zapiski TNIIYALI. Kyzyl. Vol. 5, pp. 142-158. (In Russ.).

Aranchyn, Yu. L. (1982) Istoricheskij put' tuvinskogo naroda k socializmu [The historical path of the Tuvan people to socialism]. Novosibirsk, Nauka. 337 p. (In Russ.).

Bezgin, V. B. (2015) Volostnoi sud: osobennosti sudoproizvodstva [Volost' courts: features of legal proceedings]. In: Nauchnye trudy. Rossijskaya akademiya yuridicheskih nauk [Research papers of the Russian Academy of Law], ed. by V. V. Grib. Moscow, Yurist. 1320 p. Pp. 68-72. (In Russ.).

Grumm-Grzhimailo, G. E. (1930) Zapadnaya Mongoliya i Uryanhaiskii krai [Western Mongolia and Uryankhai Territory]. Vol. III, issue 2. Moscow, Leningrad. 859 p. (In Russ.).

Damdynchap, V. M. (2006) Vladenie i sobstvennost' v obychnom prave tuvintsev [Ownership and property in Tuvan customary law]. In: Pravo $v$ zerkale zhizni. Issledovaniya po yuridicheskoj antropologii [Law in the mirror of life. Studies in legal anthropology], ed. by N. I. Novikova. Moscow, Publishing house «Strategiya». 400 p. Pp. 215-231. (In Russ.).

Damdynchap, V. M. (2009) Pravovaya akkul'turatsiia obychnogo prava tuvintsev [Legal acculturation of Tuvan customary law]. In: Narody i kul'tury Yuzhnoi Sibiri i sopredel'nykh territorii: istoriya, sovremennoe sostoyanie, perspektivy [Peoples and cultures of southern Siberia and adjacent territories: history, current state, prospects]. Ed. by V. N. Tuguzhekova. Abakan, Hakasskoe knizhnoe izd-vo. 186 p. Pp. 73-78. (In Russ.).

Datsyshen, V. G. (2002) Usinskii pogranichnyi okrug. Vlast' i obshchestvo v pogranichnom regione [Usinsk border district. Power and society in a border region]. In: Vlast' i obshchestvo. Regional'nye aspekty problemy. (K 180-letiyu obrazovaniya Enisejskoj gubernii) [Power and society. Regional aspects of the problem. (To the 180th anniversary of the formation of the Yenisei province)] / ed. by V. I. Fedorova. Krasnoyarsk, Klaretianum. 186 p. Pp. 34-37. (In Russ.).

Datsyshen, V. G. (2005) Sayanskii rubezh. Yuzhnaya chast' Prienisejskogo kraya i russko-tuvinskie otnosheniya 1616-1911 gg. [The Sayany line. The southern part of the Yenisei region and the RussianTuvan relations in 1616-1911]. Tomsk, STT. 250 p. (In Russ.).

Dulov, V. I. (1956) Sotsial'no-politicheskaia istoriya Tuvy: XIX - nachalo XX v. [Social and political history of Tuva: 19th and early XX century]. Moscow, AN SSSR Publ. 326 p. (In Russ.).

Iezuitov, V. M. (1956) Ot Tuvy feodal'noi $k$ Tuve sotsialisticheskoi [From feudal to socialist Tuva]. Kyzyl, Tuvan book publisher. 208 p. (In Russ.). 
Istoriya Tuvy [The History of Tuva] (1964) / ed. by S. K. Toka. Moscow, Nauka. Vol. I. 455 p. (In Russ.).

Istoriya Tuvy [The History of Tuva] (2001) / ed. by S. I. Vainshtein and M. H. Mannai-ool. Novosibirsk, Nauka. Vol. I. 367 p. (In Russ.).

Kon, F. Ya. (1914) Usinskii kraj [Usinsky region] / Notes of the Krasnoyarsk subdivision of the IRGO. Notes on Geography. Vol. II. Issue I. Krasnoyarsk, Printing house M. I. Abalakov. 111 p. (In Russ.).

Kuznecov, S. V. (1999) Obychnoe pravo v russkoi derevne i gosudarstvennoe zakonodatel'stvo vo vtoroi polovine XIX veka [Customary law in the Russian countryside and state legislation in the second half of the 19th century]. Etnograficheskoe obozrenie, no. 5, pp. 97-110. (In Russ.).

Menshchikov, I. S. (2016) Volostnoi sud kak khranitel' traditsionnykh norm povedeniya v russkoi derevne [Volost' court as a keeper of the traditional norms of behaviour in the Russian countryside]. Historical, philosophical, political and legal sciences, cultural studies and art history. Theory and practice, no. 6-1 (68), pp. 119-124. (In Russ.).

Rodevich, V. (1910) Ocherk Uryankhaiskogo kraya (Mongol'skogo basseina reki Eniseya) [Essays of the Uryankhai region (Mongolian basin of the Yenisei River)]. St. Petersburg, Tipografiya Ministerstva putei soobshcheniya. 268 p. (In Russ.).

Tatarinceva, M.P. and Storozhenko,A. A. (2015) Staroobryadtsyv Tuve: retrospektiva i sovremennost' [Old Believers in Tuva: a retrospective and modernity]. LAP LAMBERT Academic Publishing. 144 p. (In Russ.).

Ustanovlenie pokrovitel'stva Rossii nad Tuvoi v $1914 \mathrm{~g}$. [Establishment of the patronage of Russia over Tuva in 1914] (1994) : Archival documents / comp. by V. A. Dubrovskii. Kyzyl, Tuvan book publisher. 36 p. (In Russ.).

Submission date: 20.12.2018. 